\title{
The Role of Age in Jury Selection and Trial Outcomes
}

\section{Shamena Anwar}

Carnegie Mellon University
Patrick Bayer

Duke University
Randi Hjalmarsson

Queen Mary, University of London

May 2013

ERID Working Paper Number 146

This paper can be downloaded without charge from the Social Science Research Network Electronic Paper Collection: http://ssrn.com/abstract=2266613

\section{Economic Research Initiatives at Duke WORKING PAPERS SERIES

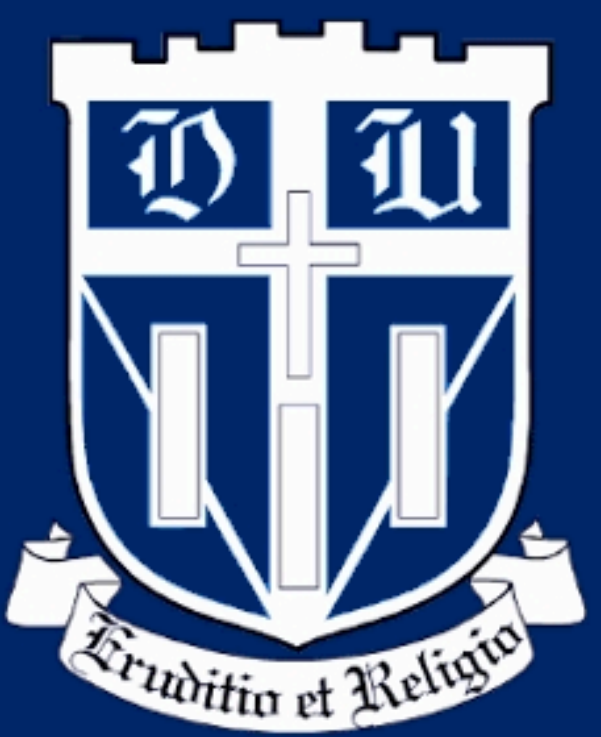




\title{
THE ROLE OF AGE IN JURY SELECTION AND TRIAL OUTCOMES
}

\author{
SHAMENA ANWAR \\ PATRICK BAYER \\ RANDI HJALMARSSON
}

\begin{abstract}
May 2013
Abstract

This paper uses data from 700+ felony trials in Sarasota and Lake Counties in Florida from 2000-2010 to examine the role of age in jury selection and trial outcomes. The results imply that prosecutors are more likely to use their peremptory challenges to exclude younger members of the jury pool, while defense attorneys exclude older potential jurors. To examine the causal impact of age on trial outcomes, the paper employs a research design that isolates the effect of the random variation in the age composition of the pool of eligible jurors called for jury duty. Consistent with the jury selection patterns, the empirical evidence implies that older jurors are significantly more likely to convict. Results are robust to the inclusion of broad set of controls including county, time, and judge fixed effects. These findings imply that many cases are decided differently for reasons that are completely independent of the true nature of the evidence in the case - i.e., that there is substantial randomness in the application of criminal justice.
\end{abstract}




\section{Introduction}

The Sixth Amendment right to a fair and impartial jury of one's peers is the bedrock of the American criminal justice system. Yet citizens are not randomly chosen to sit on juries. Instead, attorneys have the power to shape the composition of the seated jury through the use of peremptory challenges. ${ }^{1}$ Historically, such challenges could be used to exclude potential members of the jury "without cause, without explanation and without judicial approval" and, not surprisingly, this has raised concerns about the systematic exclusion of jurors on the basis of observable attributes (e.g., race, gender, age) and the ultimate impartiality of seated juries.

In recent years, in Batson v. Kentucky (1986) and J.E.B. v. Alabama (1994), the US Supreme Court has ruled that challenges motivated solely by race or gender violate the equal protection clause of the US Constitution. The Court has not extended this protection to any other category of juror characteristics and thus, under current case law, it is perfectly legal for attorneys to exclude potential jurors on the basis of any other juror attribute. ${ }^{2}$ A spirited debate continues in the courts and academy about whether discrimination on these bases should be allowed and even whether peremptory challenges should be abolished altogether. ${ }^{3}$

With this broad debate in mind, the goal of this paper is to examine the role of an important unprotected category, age, in jury selection and trial outcomes. To date, very little is known about whether attorneys systematically exclude potential jurors on the basis of age or whether juror age is even a clear predictor of conviction rates. ${ }^{4}$ The lack of compelling evidence to date is likely due, in large part, to the fact that few courts systematically collect age-specific data for summoned and/or seated jurors (Entzel, Dunlop, and Rothman 2000). A sparse literature has examined the relationship between juror age and trial outcomes using post-trial surveys of jurors; these studies have generally found no evidence or inconsistent evidence of an effect of juror age on verdict, but potential biases due

\footnotetext{
1 See Beck (1998) or Page (2005) for more detailed discussion of the historical evolution of the use of peremptory challenges in the United States.

2 One exception is the Connecticut Supreme Court's extension to outlaw peremptory challenges on the basis of religion (State v. Hodge 1999).

3 Weber v. Strippit, Inc (1999) declined to extend Batson to peremptory challenges based on age. See also Marder (1995), Reid (2004), Montz and Montz (2000), Fahey (1997), Chase and Graffy (1997), Montoya (1996), Broderick (1992), Hoffman (1997), and Page (2005).

${ }^{4}$ Age discrimination has been studied extensively in the labor market and other contexts - see, for example, Johnson and Neumark (1997), Macinol (2005) and Neumark and Stock (1999).
} 
to the non-random selection of the jury have not been addressed in this literature. ${ }^{5,6}$ There is also limited evidence, though much of it is anecdotal, that attorneys exercise their peremptory challenges to exclude jurors on the basis of age. ${ }^{7,8}$

To examine the role of age in jury selection and decisions, we have assembled a data set for over 700 felony trials in Lake and Sarasota Counties, Florida between 2000-2010. In both counties, we observe the race, gender, and age not only of each member of the seated jury but also the jury pool. This allows us to examine how juror attributes affect the propensity of members of the jury pool to be seated. ${ }^{9}$ Moreover, for Lake County, we observe the reason that an excluded member of the jury pool did not make it onto the seated jury - i.e., whether he/she was excluded for cause, or excluded by a peremptory challenge by the prosecutor or defense attorney, respectively. Finally, for each trial we observe detailed information about the defendant and criminal charges as well as the jury's verdict on each charge.

Our analysis proceeds in two main parts. We begin by examining the role of juror age in the selection process. Using the Lake County data, we show that prosecutors are systematically more likely to exclude younger members of the jury pool, while defense attorneys do the exact opposite they disproportionately exclude older members of the jury pool. As a result, both the youngest and oldest members of the jury pool are less likely to be seated than those in the middle of the age distribution. Interestingly, this pattern of selection contrasts with that for the protected categories of race and gender. For these categories, we find that both sides (prosecutors and defense attorneys) are

\footnotetext{
5 There is a much more extensive literature that looks at other demographic characteristics, such as race and gender, using both post-trial surveys and mock juries; mock juries have not been extensively used to study age. Reviews of this research indicate that there is little evidence of a consistent and significant relationship between demographic characteristics and verdicts in criminal trials (Devine et al 2000, Bonazzoli 1998-1999, and Overland 2008).

6 See Garvey et al (2004), Mills and Bohannon (1980), Baldwin and McConville (1980), Moran and Comfort (1982), and Eisenberg et al (2001) for examples of studies of the relationship between juror age and verdict that rely on juror recall.

7 Many attorneys openly acknowledge using age as one basis for peremptory challenges. It is also routine for age-based explanations to be offered to the courts when peremptory strikes are alleged to be improperly based on race and/or gender. See Entzel, Dunlop and Rothman (2000) for relevant cases.

${ }^{8}$ Baldus et. al (2001) study the use of peremptory strikes in Philadelphia capital cases. With regards to age, they found that prosecutors were more likely to strike younger jurors while the opposite was found for the defense.

${ }^{9}$ In Anwar, Bayer, Hjalmarsson (2012), we use this data to study the impact of jury race on verdict. We find evidence that: (i) juries formed from all-white jury pools convict black defendants significantly (16 percentage points) more often than white defendants and (ii) this gap in conviction rates is entirely eliminated when the jury pool includes at least one black member.
} 
about equally likely to exclude white versus black and male versus female members of the jury pool.

Having established the systematic use of age in jury selection, the second part of our analysis considers the role of juror age on trial outcomes. Establishing the causal impact of any juror characteristic on trial outcomes is generally not straightforward, precisely because of the peremptory challenge process. In particular, the seated jury on any trial is made up of those members of the jury pool that made it through the jury selection process and, as a result, the composition of the seated jury is certainly not random. Given concerns about the non-random selection of the seated jury, our research design instead exploits the variation in the composition of the jury pool across trials, which is driven primarily by which eligible jurors in the county are randomly called for jury duty on a given day. ${ }^{10}$ In essence, we examine how conviction rates vary with the age composition of the jury pool rather than the seated jury. This day-to-day variation in the composition of the jury pool does in fact appear to be random - the composition of the pool is uncorrelated with the characteristics of the defendant and the criminal charge. Importantly, the age composition of the jury pool is also highly correlated with the composition of the seated jury: a higher fraction of older (younger) jurors are seated when there is a higher fraction of older (younger) jurors in the pool drawn for that trial.

The evidence regarding the impact of the jury pool on conviction rates is straightforward and striking: when the average age of the jury pool is greater than 50 (which happens in about half of the trials), defendants are convicted 79 percent of the time. In contrast, when the average age of the jury pool is less than 50 , conviction rates are only 68 percent. These differences are statistically significant. More generally, we find that conviction rates increase by about 1 percentage point for each year increase in the average age of the jury pool. A clear and robust relationship between the jury age and conviction rates is also evident in instrumental variable (IV) regressions of conviction rates on the age of the seated jury that use corresponding measures of the jury pool as instruments. Tracking the reduced-form results very closely, our preferred IV estimates imply that conviction rates increase by 1 percentage point with each year increase in the average age of the seated jury and are 15 percentage

\footnotetext{
${ }^{10} \mathrm{~A}$ handful of studies utilize random variation in other aspects of the criminal justice system. Abrams, Bertrand, and Mullainathan (forthcoming) use the random assignment of judges to study racial disparities in sentencing. Kling (2006) uses random judge assignment as a source of exogenous variation in sentence length. Abrams and Yoon (2007) use the random assignment of felony cases to public defenders to study the effect of attorney ability on case outcomes.
} 
points higher when the average age of the seated jury is greater versus less than 50 . Our findings are robust to the inclusion of a broad set of controls for the racial and gender composition of the jury and a series of county, time, and judge fixed effects. A qualitatively similar pattern of results is found in both Lake and Sarasota Counties.

While the effects of jury age on conviction rates do not vary with the race of the defendants, they do vary with the gender of the defendant. Because the majority of the defendants in the sample are male, the results for male defendants mirror the overall results closely, revealing a strong positive relationship between jury age and conviction rates. The results for female defendants, on the other hand, reveal a strong negative relationship between jury age and conviction rates. This suggestive finding raises the possibility that older jurors may be more sympathetic to female defendants or may have lower initial priors about their criminality.

A limitation of the analysis that we conduct in our paper, and essentially any analysis like it, is that ultimately we cannot say for certain whether it is age itself, rather than unobserved factors correlated with age, that drive our results related to jury selection and decision-making. We close the paper, therefore, with a more general examination of the relationship between age and conservatism, especially as it relates to issues of criminal justice. Since the existing academic literature reports mixed results, we conduct our own analysis of the age-conservatism link using the 1972 to 2010 rounds of the General Social Surveys. We consider three survey questions that assess whether individuals: (i) are in favor of the death penalty for persons convicted of murder, (ii) believe their local courts are too harsh, too lenient, or about right towards criminals and, (iii) consider their own political views to be liberal or conservative. In each case, the results reveal that conservatism increases significantly with age, especially between the ages of 20 and 40. Interestingly, non-parametric plots of conviction rates by the average age of the jury pool also reveal a much steeper relationship at lower ages, suggesting that our main results are driven primarily by shifting from especially young pools to those closer to the median.

The remainder of the paper proceeds as follows. Section II provides background information on jury selection in Sarasota and Lake County while Section III describes the data. Section IV presents our analysis of the jury selection process and Section V presents our findings on the impact of jury age 
composition on conviction rates, including a number of alternative specifications that establish the robustness of our main findings. Section VI discusses the relationship between age and conservatism. Finally, Section VII concludes by discussing the implications of our findings for the equal application of the law.

\section{The Jury Selection Process}

Our analysis is based on a sample of non-capital felony jury trials in Sarasota County and Lake County, Florida. Each county has a master jury list, which is a list of potential jurors that is compiled from driver's license records. Both counties use a jury management software program to randomly choose individuals from this master list to receive a summons requesting that they appear at the courthouse on a particular date. Potential jurors are only eligible to serve if they are a U.S. citizen, are a legal resident of either Sarasota or Lake County, able to speak/understand English, and not under a legal disability (felony conviction or incompetence). In addition, some individuals who receive a summons are eligible for an automatic exemption and need not appear in court. ${ }^{11}$

Individuals who are not exempt and who are eligible to serve check-in on the date summoned; upon check-in, they are entered into the jury management software program, which randomly chooses individuals to participate in a particular panel. It is important to note that the jury management software program only utilizes data about jurors and does not have information about the defendants or case characteristics. Individuals whose names are called out enter the courtroom to participate in voir dire.

During the voir dire process, both the attorneys (defense and prosecution) and the judge ask the potential jurors a series of questions, which are designed to determine whether the individual is fit to serve as an impartial member of the jury. Some individuals are simply excused from service, perhaps because of a medical condition. Other individuals are removed for cause by the judge because they cannot be impartial or follow the law. Both prosecutor and defense attorneys can request a

\footnotetext{
${ }^{11}$ Individuals can be automatically excused if: (i) they are an expectant mother, (ii) they are a parent who is not employed full time and has custody of a child under 6, (iii) they are a full time law enforcement officer, (iv) they served as a juror in Sarasota county in the last 365 days, (v) they are responsible for the care of another who is incapable of caring for himself, or (vi) they are 70 or older and wish not to report (at this time or permanently).
} 
removal for cause, and there is generally no limit to the number of such requests. Finally, both the prosecutor and defense attorneys have the option to use peremptory challenges to strike potential jurors from the jury. Such challenges are differentiated from removals for cause in that attorneys do not have to state the reason for the strike and there are a limited number of peremptory challenges available to both the prosecution and defense. Though the attorneys do not have to provide a reason for dismissing a juror, a peremptory challenge cannot be used to strike a juror solely on the basis of race or gender, although striking based on age is permitted. If the offense is punishable by imprisonment of more than 12 months, then attorneys for both the defense and prosecution have six challenges; for all other offenses, there are three challenges. The first six jurors to survive the voir dire make up the seated jury. In addition, 0-2 alternate jurors are also chosen at this time through the same process. ${ }^{12}$

After hearing the evidence, the six seated jurors need to come to a unanimous decision of guilty or not guilty for each of the defendant's charges. If jurors cannot come to a unanimous decision for a particular charge, there will be a hung jury for that charge. This typically results in the defendant being retried on that particular charge. ${ }^{13}$

\section{Data}

\section{III.A. Description of Jury Data from Sarasota and Lake Counties}

Our analysis is conducted using felony jury trial data for Lake County and Sarasota County, Florida. As each county circuit court maintains their own records of jury trials, these data were obtained through separate requests to each county. ${ }^{14}$ Since a standardized record system is not used

\footnotetext{
${ }^{12}$ The jury selection process described above pertains only to non-capital cases in Lake and Sarasota County. While many of the core details remain the same, the process can vary slightly when considering different jurisdictions or capital cases. The main differences are where the master jury list is composed from, the number of peremptory challenges the prosecution and defense have, and the size of the seated jury.

${ }^{13}$ Since a hung jury is an interim disposition from the court's perspective, most courts do not systematically collect and publish statistics regarding hung jury rates (Hannaford-Agor et. al 2002). Hannaford-Agor et. al (2002) began to address this issue in a study of hung jury rates for 30 state courts and federal courts between 1980 and 1997. They found that about five percent of state felony jury trials resulted in a hung jury, though there was substantial variation across jurisdictions. Federal hung jury rates for criminal trials were even lower, between two and three percent, and those for civil trials were lower still.

${ }^{14}$ To obtain the data used in this paper, we sent data request letters to every felony court in fifteen states. Most courts indicated that they were unable to provide data because either judicial records are excluded from public records request or these data are not collected or maintained.
} 
throughout Florida, the type of information and format of the data available vary somewhat across counties. Thus, the majority of our analysis is conducted with a single, combined data set of Lake and Sarasota County trials, using those variables that can be commonly identified in both counties. The following is a brief description of the data obtained for each county as well as the combined data set.

The office of the Clerk of the Sarasota County Circuit Court provided us with information on all felony trials for which jury selection began between January 1, 2004 and June 1, 2009. ${ }^{15}$ For each trial, we have data for both the defendant and the jury. The defendant data includes the name, race, and gender of the defendant as well as information about the charged offenses, including a detailed crime code, the date that the offense was filed, the date that the judgment was handed down, and the verdict for each offense. For our main analysis, we restrict our sample to trials in which at least one of the charged offenses resulted in a verdict of guilty or not guilty by the jury. ${ }^{16}$ The jury data includes the name, date of birth, gender, and race of each individual in the jury pool as well as whether or not they were seated. However, we cannot distinguish between individuals who are seated and those who became alternates; all of these individuals appear to be 'seated'.

Data were also provided to us by the Lake County Clerk of Courts for all felony jury trials from March 1, 2000 to April 2, 2010. As in Sarasota County, we know each potential juror's name, race, gender, date of birth, and whether they were seated or assigned as alternates. In addition to this, we also know whether jurors were struck for cause or whether the prosecution or defense struck them with their peremptory challenges. This information is not available in Sarasota County. In terms of the defendant information, the Lake County Clerk of Courts only provided the case number and defendant name. We used this information to manually collect the following information from the Lake County Clerk of Courts Online Court Records website: city of residence, sex, race, attorney, judge, the number of charges, the type of charge, and the verdict for each charge ${ }^{17}$ As in Sarasota, we

\footnotetext{
${ }^{15}$ Note that because of the (oftentimes long) lag between the date at which an offense is filed with the courts and the date at which a verdict is rendered, our data set contains trials for offenses dating as far back as 1999 .

${ }^{16}$ Charges for which the verdict was neither guilty nor not guilty had the following possible outcomes: dropped, noelle prosequi, filed, dismissed due to speedy trial, dismissed with no reason given, consolidated, adjudication withheld by judge and unable to stand trial. We test the sensitivity of our results to the exclusion of these cases in Table 7.

${ }^{17}$ The data were collected from the following website: http://www.lakecountyclerk.org/record_searches/court_records_agreement.aspx?to $=\% 2$ Frecord $\% 5$ Fsearches $\% 2$ Fonline $\% 5$ Fcourt $\% 5$ Frecords $\% 2$ Fonline $\% 5$ Fcourt $\% 5$ Frecords $\% 2$ Easp?target $\% 3 \mathrm{D} \% 5 \mathrm{Fblank}$.
} 
restrict our sample to trials in which at least one of the charged offenses resulted in a verdict of guilty or not guilty by the jury. ${ }^{18}$

Since all felony trials in Florida other than capital trials have six-member juries, we exclude capital trials from our analysis. Since each jury should have six members plus zero to two alternates, we drop those cases with less than six jurors/alternates identified in the data and those with more than 8. We also drop those cases with multiple defendants and those in which the defendant names do not match the online record (i.e. in Lake County). We are left with a dataset of 785 felony jury trials, 401 of which are from Sarasota County and 384 of which are from Lake County.

\section{III.B. Summary Statistics}

Table I presents descriptive statistics for both the defendant and jury variables for all 785 felony trials overall and separately for Lake and Sarasota counties. Overall, 44 percent of defendants are black, and 92 percent are male. The average number of charges per defendant is 2.99 . We identify whether each defendant is charged with an offense in the following categories, regardless of the verdict associated with the charge: murder (non-capital), robbery, other violent offenses, property offenses, drug offenses, sex offenses, weapons offenses, and other offenses. Overall, the most common crime categories are other offenses (33 percent), other violent offenses ( 31 percent), and drug offenses (25 percent).

We consider two possible outcome measures or verdicts: whether the defendant was convicted of at least one offense and the percent of the first five offenses for which the defendant was convicted. 72.8 percent of defendants were convicted of at least one offense. On average, seated juries have seven members (including alternates) drawn from jury pools with 27 individuals. In Lake County, where we have detailed strike information, we find that on average 2.2 jurors in the pool are struck for cause, 4.5 jurors are struck by a defense peremptory challenge, and 3.4 jurors are struck by a prosecution peremptory challenge.

\footnotetext{
${ }^{18}$ Other possible verdicts include: pled, nolle prosequi, no information, dismissed by judge, and mistrial. We will test the sensitivity of our results to redefining pleas as decisions of guilty by the jury.
} 
The average age of jurors in the pool is 49.6 years, and 46 percent of jury pools have an average age that is greater than or equal to 50 years. The age composition in Sarasota County is slightly older (49.9) than in Lake County (49.4). The average age of the seated jury tends to be slightly older than the average age of the pool, implying older jurors are more likely to be seated. While this difference is observed in both counties, it is more pronounced in Sarasota County. ${ }^{19}$

\section{The Role of Juror Demographics in the Selection Process}

As mentioned previously, it is perfectly legal for attorneys to use their peremptory challenges to exclude potential jurors on the basis of age. If attorneys use these challenges as a strategic way to eliminate jurors that are unfriendly to their case due to their age, we would expect the defense strike pattern to be the opposite of the prosecution strike pattern. Column 1 of Table 2 examines whether this is the case for Lake County, where we observe information about the use of peremptory challenges by each side. The regression includes the entire pool of Lake County jurors. We regress the juror's age on indicator variables for whether she/he was struck for cause, struck by a defense peremptory challenge, struck by a prosecution peremptory challenge, or remained in the jury pool after the selection process was over. ${ }^{20}$ The excluded category is an indicator for whether the individual was on the seated jury for the trial. The results show that the average seated juror is 49.4 years old, while the average juror struck by the defense is 51.6 years old, and the average juror struck by the prosecution is 47.1 years old. This implies that defense attorneys strike relatively older members of the jury pool while prosecutors strike relatively younger ones. We find the same pattern of results in Column 2 where our dependent variable is an indicator for whether a juror's age is 50 or greater. These results are consistent with the Baldus et. al (2001) findings that prosecutors of Philadelphia

\footnotetext{
${ }^{19}$ While not reported in Table I, the average composition of the jury pools is 4 percent black and 51 percent female.

${ }^{20}$ Some of these jurors remaining in the pool were suitable to be seated but were not needed. Others were so far back in the pool they did not even go through the questioning process that could potentially have led to them being struck.
} 
capital cases were more likely to strike young jurors while the opposite was true for defense attorneys. $^{21}$

In Columns 3 and 4, the dependent variable is defined as an indicator for whether the juror is male, and an indicator for whether the juror is black, respectively, to examine the strike pattern for the protected categories of gender and race. The results in Column 3 imply that attorneys do not systematically use gender as a factor when they use their peremptory challenges, because both the prosecution and defense are just as likely to strike male jurors as they are female jurors. The results for race in Column 4 show that both the defense and prosecution are less likely to strike black jurors than white jurors. ${ }^{22}$ Technically, this means attorneys are taking race into account when they make their strike decisions. However, they do not seem to be doing this in a strategic way (i.e. using race as a factor to strike jurors unfriendly to their case), because otherwise we would expect one side to be more likely to strike black jurors, and the other group to be less likely. The fact that both attorneys are less likely to strike black jurors might instead indicate attorneys go overboard in not striking blacks so they cannot be accused of violating the ruling in Batson v. Kentucky. This is especially likely to be a concern in Lake County where only 5 percent of the jury pool is black, making it easy to notice the systematic use of peremptory challenges to exclude black jurors.

Table 3 examines in more detail the strike patterns by age revealed in the first two columns of Table 2. We regress an indicator variable for why the juror was struck on juror age group indicator variables, where the omitted age category is whether a juror is age 30 or younger. The results in Column 1 imply there is no relationship between juror age and being struck for cause. Column 2 shows that 13 percent of the jurors that are 30 or younger are struck by the defense. The likelihood of being struck by the defense increases monotonically in juror age; jurors greater than 60 years old have a 20 percent chance of being struck by the defense. In contrast, column 3 shows that the probability of

\footnotetext{
${ }^{21}$ More specifically, Baldus et, al. (2001) find that the odds of a prosecutor striking a young venire member relative to a middle aged venire member are 1.8 while those of striking an old member relative to a middle aged are 0.81 . For the defense, the odds of striking a young venire member relative to one who is middle aged are 0.72 while the odds of striking an old member relative to a middle aged member are 1.3. It should be kept in mind that peremptory challenges may play a much larger role in death penalty cases, at least in Philadelphia where each side has 20 peremptory strikes available in a single defendant case. In contrast, the felony cases studied in the present paper have at most six strikes.

${ }^{22}$ This same result occurs for the subsamples of cases involving only black defendants or only white defendants.
} 
being struck by the prosecution is highest for younger jurors and continues to decrease as juror age increases.

The limited existing literature on jury selection has been largely written by trial consultants and is inconclusive about the role of age. ${ }^{23}$ Entzel, Dunlop, and Rothman (2000) cite a 1991 American Bar Association report that indicates that older members of the venire may be struck because they are "stubborn, indecisive, or cantankerous." Other experts do not view age as an important factor for jury selection. For example, Sean Overland, a trial consultant, writes in a 2009 article that he has not found any evidence of an age-verdict relationship in his own analysis of thousands of mock jurors. ${ }^{24}$ Kressel and Kressel's (2004) book on the jury consulting science notes that social psychologists have searched for a formula based on individual characteristics and traits, including for instance whether 'older people are more likely to vote guilty', that will identify which jurors will vote for a conviction; however, they conclude that there is no single profile of the ideal juror and that if individual characteristics play any role in determining verdicts, it will vary on a case by case basis. ${ }^{25}$ In the context of this broader literature, our results contribute strong statistical evidence from real felony trials that age plays a systematic role in jury selection.

\section{The Effect of Juror Age on Conviction Rates}

The difference in defense and prosecution strike patterns by juror age suggests that attorneys believe age is correlated with the likelihood of voting to convict or acquit. We now take up this question directly, examining the causal impact of juror age on trial outcomes. The dashed line in Figure 1 shows that the probability a defendant is convicted of at least one crime increases systematically with the average age of the seated jury. As shown in the previous section, however, the

${ }^{23}$ In high-profile cases, trial consultants often conduct phone surveys prior to jury selection to collect demographic and attitude behavior for a relevant sub-sample of the population. Paul Lisnek (2003), one such trial consultant, writes that these "demographic questions ultimately assist in creating the juror profile of both desirable and undesirable jurors. Lawyers want to know, as a guideline, whether desired jurors tend to be of a certain race, sex, age group, and such."

${ }^{24}$ Generational Differences in the Jury: Much Ado About Nothing?, Overland Consulting Blog, Dec 16, 2009.

${ }^{25}$ Other trial consultants emphasize that these generational differences are important factors when helping an attorney determine the best way to present their case to the jury; for instance, older individuals respond differently to graphics, narratives, metaphors, or pretrial publicity. See for instance, "Intergenerational Law Offices, Intergenerational Juries: Values, Priorities and Decision Making," by Douglas Keene and Rita Handrich from Keene Trial Consulting. , January 31, 2013. The Jury Expert. http://www.thejuryexpert.com/2013/01/ 
seated jury is determined in part by the selective use of peremptory challenges and this raises the concern that the correlation between the composition of seated jury and trial outcomes may be driven by selection bias.

We deal with this selection problem in two ways. In Section V.A. we use a reduced form approach and examine how conviction rates respond to the age composition of the jury pool, as this variation is driven by the automated random selection of the eligible jurors who are called for jury duty on a given day. The solid line in Figure 1 presents a graphical representation of this reduced form relationship. There is a clear positive relationship between the average age of the jury pool and the conviction rate that appears to be stronger than the relationship observed when looking at the average age of the empaneled jury.

In Section V.B. we directly examine the causal relationship between the age of the seated jury and conviction rates by instrumenting for the age of the seated jury with the age of the jury pool. As Figure 2 shows, the age of the jury pool is highly predictive of the age of the seated jury, and is thus a strong instrument for the age of the seated jury; the first stage regression results and corresponding Fstatistics show this more formally. In addition, we show that our central result of a positive relationship between juror age and conviction rates is robust to a variety of instrumental variable specifications.

\section{V.A. Reduced Form Results}

Before presenting our main results, we first test that the foundation of our research design is valid - i.e., that the composition of the jury pool is effectively random. To this end, Table 4 examines the correlation of the composition of the jury pool with defendant and case characteristics. Specifically, we regress the average age of the pool, an indicator for whether the average age of the pool is greater than or equal to 50 , the proportion of the pool that is female, and the proportion of the pool that is black on observable defendant and case characteristics. ${ }^{26}$ If the jury pool were truly randomly assigned to cases, the regression coefficients should be close to zero and statistically insignificant in the vast majority of cases. This is exactly what we find, as just three of the 48

\footnotetext{
${ }^{26}$ Note that 14 cases are dropped from these regressions due to incomplete charge information.
} 
coefficients presented in this table are statistically significant at the 10 percent level and the magnitudes of all coefficients are quite small. These results suggest that the jury management software properly randomly selected both the potential jurors from the master list to receive summons for jury duty and the pool of jurors from those summoned on a given day to participate in voir dire for a particular trial.

Table 5 presents simple cross tabulations showing how conviction rates vary with the average age of the jury pool. There is a general upward trend - defendants are more likely to be convicted as the average age of the pool increases. In particular, the table indicates that there is a sharp difference in conviction rates between jury pools that have an average age of 50 or older versus those with an average age less than 50 .

Table 6 examines the relationship between conviction rates and the age of the jury pool in regression form. Column 1 regresses an indicator of whether a defendant is convicted of at least one crime on the average age of the jury pool. The results indicate that increasing the average age of the jury pool by one year increases conviction rates by one percentage point. The specification in Column 2 includes controls for the racial and gender composition of the jury pool, defendant and case characteristics (race, gender, offense category and number of offenses), as well as county, year and judge controls. Including controls for other characteristics of the jury pool accounts for potential correlations between jury race, gender, and age. The coefficients on the age of the jury pool are similar across both specifications.

Columns 3 and 4 of Table 5 repeat the previous specifications using an indicator for whether the average age of the pool is greater than or equal to 50. The use of this indicator, which effectively splits the sample in half, is a more robust way to measure the relationship between jury age and conviction rates if the effect of age is not strictly linear, which the previous specification requires. Consistent with this notion, the statistical power of the impact of age on conviction rates is stronger in this specification. In particular, Column 3 indicates that when the average age of the jury pool is greater than or equal to 50 , defendants are convicted 79 percent of the time. When the average age of the jury pool is less than 50, conviction rates are only 68 percent. Columns 5-8 repeat the same structure of the first four columns using the fraction of the first five offenses on which the defendant 
was found guilty as the dependant variable. The results are quite similar in magnitude, although not all of the age coefficients are statistically significant.

Table 7 examines whether the relationship between juror age and conviction rates varies by defendant characteristics. To determine whether this relationship depends on defendant gender, Columns 1 and 2 regress whether a defendant is convicted of at least one crime on a measure of the age of the jury pool, whether the defendant is female, and an interaction of the two variables. The regressions also include controls for jury gender, race, and county, which are fully interacted with defendant gender; we also include controls for defendant race, crime type and total charges which are fully interacted with the age measure of the jury pool. ${ }^{27}$ The results in Column 2 indicate that for male defendants, when the average age of the pool goes from below 50 to 50 or above, the conviction rates increase from $66 \%$ to $79 \%$. However, for female defendants the opposite pattern is observed as the conviction rate declines from $95 \%$ to $71 \%$. Because over 90 percent of the defendants are male, the overall pattern between juror age and conviction rates found in Table 6 mirrors that of male defendants.

Columns 3 and 4 of Table 7 perform a similar analysis, but now allow the relationship between juror age and conviction rates to depend on whether a defendant is black. These regressions restrict the sample to cases involving black and white defendants only. Again, we include controls for jury gender, race, and county which are fully interacted with defendant race; we also include controls for defendant gender, crime type and total charges which are fully interacted with the age measure of the jury pool. ${ }^{28}$ The results in Column 4 imply that the increase in conviction rates due to juror age is similar for cases involving black versus white defendants. Thus, the effects of juror age on conviction rates do not vary with the race of the defendant.

Table 8 considers some additional robustness checks on the main result found in Table 6 . All specifications include the full set of controls, and use an indicator for whether the average age of the jury pool is greater than or equal to 50 as a measure of juror age (akin to Table 6 , Column 4). The first

\footnotetext{
${ }^{27}$ Each control variable not shown in Table 7 is demeaned (prior to being interacted), which ensures the main coefficients in Table 7 are reported at the sample mean in each specification; thus there is no need to look at the coefficients on the interaction variables included in the vector of controls to interpret the main coefficients shown in the table.

${ }^{28}$ As above, each control variable not shown is demeaned prior to being interacted.
} 
two columns show that the positive relationship between juror age and conviction rates appears separately in both Lake and Sarasota County. Columns (3)-(6) consider the robustness of the results to alternative ways of categorizing trial outcomes that are not simple verdicts of "guilty" or "not guilty" by the jury. For instance, Column 3 redefines as guilty 133 cases in Lake County that are pled by the defendant at some point after a jury pool is chosen (but before the case actually goes to the jury). It is theoretically ambiguous whether such cases should be included in the analysis (categorized as guilty verdicts). On the one hand, it makes sense to include them if the willingness of the parties to enter into a plea bargain is affected by the composition of the jury. On the other hand, if these plea bargains are reached for reasons unrelated to the jury composition (as they would be if reached prior to jury selection), including them biases the coefficients towards zero as the outcome is, by construction, the same for all of these trials regardless of the jury composition. In about two-thirds of the pled Lake County cases, we observe data characterizing the composition of both the jury pool and a seated jury, suggesting that voir dire did actually occur in these cases, and that the plea occurred after the jury was seated. We thus conduct an additional robustness check in Column 4, and include as guilty verdicts just those Lake cases that are pled by the defendant after the jury is seated. ${ }^{29}$ Column 5 recodes those 25 Sarasota cases that did not have guilty or not guilty jury verdicts associated with them as not guilty while Column 6 repeats the same exercise, coding these cases as guilty. In all cases, the pattern of results related to juror age remains.

\section{V.B. Instrumental Variables Results}

The reduced form results presented in Tables 5-8 show the direct effect of the quasiexperimental variation in the data and are, therefore, our preferred way of examining the relationship between juror age and trial outcome. We take the analysis a step further in this subsection by presenting results from instrumental variables (IV) specifications that identify the impact of the age of the seated jury using the age of the jury pool as instruments. This analysis requires the additional

\footnotetext{
${ }^{29}$ All of the results presented in Columns 1-4 of Table 6 and all of Table 7 are robust to the inclusion of these Lake County cases that were pled after the jury was seated.
} 
assumption that the age composition of the jury pool affects trial outcomes only through its impact on the age composition of the seated jury.

We present results for a variety of IV specifications using as instruments the two measures of the age composition of the jury pool (average age, average age greater than 50) that were used in the reduced form analysis. Table 9 presents first stage regressions of seated jury age on the measures of the jury pool age, as well as the full set of controls described in Table 6. The results in Column 1 indicate that the average age of the seated jury increases by 0.94 years when the jury pool increases by one year, while those presented in Column 2 imply that the average age of the seated jury is 4.6 years higher when the jury pool is greater than 50 versus less than 50 . Both of these results are highly statistically significant. When both measures of the jury pool age are included in Column 3, predictive power loads on the average age of the pool suggesting that this variable is a better predictor of the average age of the seated jury. Columns 4-6 repeat analogous specifications using an indicator for whether the average age of the seated jury is 50 or greater as the dependent variable. Regardless of the specification used, all of the first stage results are strongly statistically significant. In particular, Fstatistics on the excluded instruments from these first stage regressions (which are shown in Table 10) are between 88 and 276 .

Table 10 presents both OLS and IV results of the impact of the seated jury on trial outcomes. Columns 1-4 use average age of the seated jury as the dependent variable. Column 1 presents the OLS results, Column 2 uses average age of the jury pool as an instrument, Column 3 uses an indicator for whether the average age of the pool is 50 or greater as an instrument, and Column 4 uses both pool age measures as instruments. While the OLS results show only a weak and statistically insignificant relationship, the IV specifications consistently pick up a significant positive relationship that is 4-10 times greater in magnitude than that implied by OLS.

The size of the estimated effect in the IV regressions depends on which instrument(s) is used - the results from Columns 2 and 4 imply that increasing the average age of the seated jury by one increases the probability of conviction by $0.9-1.0$ percentage points, while those presented in Column 3 imply an increase of 2.5 percentage points. The various IV specifications produce different results because they implicitly use different variation in the data to identify the effect - i.e., each 
specification captures a different Local Average Treatment Effect (LATE). The results presented in Column 2, for example, pick up the effect of increasing the average age of the pool across the full age range of all seated juries, as increasing the average age of the jury pool by a year raises the average age of the seated jury by about a year at all points in the age distribution. ${ }^{30}$ Not surprisingly, this specification corresponds quite closely to the reduced form results presented in Column 2 of Table 6 . Our preferred specification is that presented in Column 4, which uses both measures of the pool age composition as instruments, thereby generating as much variation in the seated jury age distribution as possible. That these results mirror those reported in Column 2 is not surprising given that predictive power in the first stage regression loads on the average age of the pool when both instruments are included.

Columns 5-8 repeat the specifications in Columns 1-4, respectively, with a new dependent variable: whether the average age of the seated jury is 50 or greater. The results are similar to those reported in Columns 1-4; the OLS results are insignificant, while all IV results show positive and significant age effects. Again we find that the age results are stronger when the indicator age variable is used as an instrument, and the results using both instruments mirror those of only using the average age of the pool as an instrument. ${ }^{31}$ Our preferred specification is that reported in Column 8 , which implies that seated juries with an average age above 50 are 15 percentage points more likely to convict than those with an average age less than 50 .

Overall, the reduced form and IV results reveal a strong positive relationship between jury age and trial outcomes regardless of the particular specification that is chosen. The OLS estimates of the effect of the seated jury on trial outcomes, in contrast, are much smaller in magnitude and statistically insignificant, suggesting that the jury selection process indeed confounds the underlying relationship between juror age and trial outcomes. This is potentially one of the reasons that the previous

\footnotetext{
30 This can be seen in Figure 2, which shows that the relationship between jury pool age and seated jury age is roughly linear throughout the age distribution.

${ }^{31} \mathrm{We}$ do not report the IV results where both endogenous age measures of the seated jury are used simultaneously. The first stage results shown in Column 3 and 6 of Table 9 imply that all the identification would likely be coming off only one of the instruments (the average age of the pool) and thus we would have an under-identified model.
} 
literature, which has typically relied on examining simple correlations between seated juror age and conviction decisions, has found no relationship between age and trial outcomes.

\section{Why Does Age Play a Role?}

The previous sections document the role juror age plays in both jury selection and trial outcomes. Unfortunately, we cannot conclude for certain whether it is age itself, or unobserved factors correlated with age, that drive these relationships. One of the key unobservable variables that age might pick up is conservatism and thus in this section we examine the relationship between these two variables in the context of the criminal justice system.

Popular stereotypes suggest that older individuals are more conservative than younger individuals, either because these older cohorts were born into a generation that is generally more conservative or because individuals become more conservative as they age. Academics have studied the relationship between aging and conservatism for many years. Much of this literature is focused on how an individual's beliefs change as they age: do they, in fact, become more conservative? Are older individuals so set in their ways that they are not willing to change their beliefs? A review of a number of early studies (Glenn, 1974) suggests people actually become less conservative as they have grown older, in conformity with general trends in society. However, he also notes that older cohorts are more conservative relative to the general population; while they became less conservative as they aged, their changing beliefs did not keep pace with younger generations. Danigelis, Cutler and Hardy (2007) use the U.S. General Social Survey data from 1972 to 2004 to study the magnitude and direction of changes in attitudes towards historically subordinate groups, civil liberties, and privacy within cohorts as they age. They find that attitudes can change at both earlier and later stages of the life cycle (i.e. that older individuals' attitudes are not completely fixed) and that the direction of change is often towards being more tolerant. In contrast, when studying law and order issues, Danigelis and Cutler (1991) have found that all generations have become more conservative. In addition, studies that consider whether 
older individuals have more conservative beliefs towards law and order issues than younger individuals have yielded mixed findings. ${ }^{32}$

Given that the relationship between age and conservatism appears to vary across studies, and in particular with respect to the topic being studied, we conduct our own analysis of the ageconservatism link using the 1972 to 2010 rounds of the General Social Surveys. We consider three survey questions that assess whether individuals: (i) are in favor of the death penalty for persons convicted of murder, (ii) believe their local courts are too harsh, too lenient, or about right towards criminals and, (iii) consider their own political views to be liberal or conservative on a scale of one to seven, where an answer of five or above indicates some degree of conservativeness.

Figure 3 presents the raw relationship between age and the answers to these questions. As individuals get older, they are more likely than younger individuals to favor capital punishment, believe that the courts are too lenient towards criminals and consider themselves politically conservative while they are less likely to believe that the courts are too harsh. While an upwards trend is observed in each of these graphs across most of the age spectrum, the gradient appears to be steepest for individuals younger than 40 .

Table 11 presents regression results that look more formally at the relationship between age and conservatism. We characterize individuals' ages as 18-29, 30-39, 40-49, 50-59, 60-69, 70-79 and 80 plus; age 18-29 is the omitted category in each regression. Column (1) of each panel presents the raw relationship for all survey rounds, with no controls. Relative to 18-29 year olds, individuals in each of the other age groups are significantly more likely to be 'conservative'. In addition, this difference is often significantly larger for the age groups over 60 than the younger age groups. For instance, respondents aged 30-39 are 4.7 percentage points more likely than 18-29 year olds to think that the courts are too lenient while those $60-69$ are 7.5 percentage points more likely to think so. The regressions presented in column (1) and the graphs discussed above, however, pool all individuals from all survey rounds; thus, we cannot rule out the possibility that the observed relationships are

\footnotetext{
${ }^{32}$ Alston (1976), Sengstock and Liang (1979), Vidmar and Ellsworth (1976), and Williams, Thomas and Singh (1983) find older individuals support harsher sanctions for criminals while Thomas and Hoard (1978) finds little difference across ages and Rugiero and Weston (1977) finds that older people are less punitive towards the death penalty.
} 
driven by changes in beliefs over time. The robustness of these results to the inclusion of survey year dummies in column (2) suggests that this is not what is underlying the age-conservatism relationship. Column (3) begins to address the question of whether it is an individual's age that drives the relationship, or something else that is correlated with age, such as gender, race, years of schooling, number of children and marital status. These variables are significant predictors of conservatism themselves and do appear to explain some of the age-conservatism relationship; however, much of the age-conservatism relationship remains over and above these controls. Finally, column (4) of each panel demonstrates the robustness of the results to restricting the sample to the 2000-2010 survey rounds, which corresponds with the years of our jury data. The same pattern of results is generally seen, though there is some loss of precision due to the reduced sample size. ${ }^{33}$

\section{Implications and Conclusion}

The main empirical findings presented in this paper provide clear statistical evidence that jury age has a causal effect on trial outcomes and that prosecution and defense attorneys take age into account when using their peremptory challenges to shape the seated jury. We conclude the paper by considering the implications of these findings for the equal application of criminal justice.

At the most foundational level, our reduced form results show that random variation in the pool of jurors called for jury duty on a given day has a substantial effect on conviction rates. In particular, if a male defendant, completely by chance, faces a jury pool that has an average age above 50 , he is about 13 percentage points more likely to be convicted than if he faces a jury pool with an average age less than 50. Put slightly differently, for reasons that are completely independent of the nature of the evidence in the case, a large fraction of cases are decided differently based simply on random variation in this single dimension of the jury pool composition. When combined with variation in other aspects of jury pool such as the racial composition (which we document has a substantial impact on conviction rates in Anwar et al. (2012)), our findings imply that there is a substantial random component in the application of criminal justice due to the jury variation.

\footnotetext{
${ }^{33} \mathrm{~A}$ similar pattern of results is also seen when using actual age as the variable of interest rather than age categories and when considering support of the death penalty as the dependent variable.
} 
Whether such randomness in the criminal justice system constitutes unfair or unequal treatment under the law depends on whether these measures are considered from an ex ante or ex post perspective. Because juries for all defendants are drawn from the same master list of eligible jurors, the system provides equal treatment from this vantage point. Yet, the fact that cases for defendants facing statistically identical evidence are decided differently in so many instances due to randomness in the jury pool suggests a fundamental lack of equity with respect to the quality of true nature of the evidence in a case.

Of course, some degree of randomness is to be expected in any jury trial setting, as juries are made up of a small subset of the full eligible population by necessity. How much randomness in trial outcomes is acceptable, however, is at the heart of the design of the jury trial system. While smaller juries, such as the 6-person juries in Florida, might save court costs, they substantially increase the variation in trial outcomes. A move to one-person juries could cut court costs even further, yet presumably such a system has been deemed socially unacceptable because it would seem capricious, even if the single juror were randomly selected. From this perspective, our paper provides the first direct evidence in the literature on the magnitude of the randomness embedded in the jury system used in these Florida counties. By examining the impact of the random variation in jury composition along the dimensions that we can observe, we provide a lower bound on how much of the variation in trial outcomes is independent of the true nature of the evidence in the case. 


\section{References}

Abrams, David, Marianne Bertrand, and Sendhil Mullainathan (forthcoming) "Do Judges Vary in Their Treatment of Race?" Journal of Legal Studies.

Abrams, David and Albert Yoon (2009),"The Luck of the Draw: Using Random Case Assignment to Investigate Attorney Ability," The University of Chicago Law Review, 74:4, 1145-1177.

Alston, Jon. (1976) "Japanese and American Attitudes toward the Abolition of Capital Punishment." Criminology 14: 271-76.

Anwar, Shamena, Patrick Bayer, and Randi Hjalmarsson (2012) "The Impact of Jury Race in Criminal Trials", The Quarterly Journal of Economics, 127 (2), 1017-1055.

Baldwin, J. and Mike McConville (1980), "Understanding Jury Trial: A review of the Literature on the role of the Jury in Criminal trials in the United States and England", in (ed. N. Morris and M. Tonry), Crime and Justice 1979: A review of Criminal Justice Research, University of Chicago Press.

Baldus, D. C., Woodworth, G. G., Zuckerman, D., Weiner, N. A., \& Broffitt, B. (2001). "The use of peremptory challenges in capital murder trials: A legal and empirical analysis". University of Pennsylvania Journal of Constitutional Law, 3, 3-169.

Batson v. Kentucky (1986), 476 U.S. 79

Beck, Coburn (1998), "The Current State of the Peremptory Challenge," William and Mary Law Review, 39.

Bonazzoli, M. Juliet (1998-1999). "Jury Selection and Bias: Debunking Invidious Stereotypes through Science”. Quinnipiac Law Review, 18: 247.

Broderick, Raymond, (1992) "Why the Peremptory Challenge Should Be Abolished," 65 Temple Law Review 369

Chase, Carol and Colleen P. Graffy (1997) "A Challenge for Cause to Peremptory Challenges in Criminal Proceedings," 19 Loyola of Los Angeles International and Comparative Law Review 507.

Danigelis, Nicholas and Stephen Cutler (1991) "Cohort Trends in Attitudes About Law and Order: Who's Leading the Conservative Wave?" Public Opinion Quarterly 55:24-49.

Danigelis, Nicholas, Melissa Hardy, and Stephen Cutler (2007) "Population Aging, Introcohort Aging, and Sociopolitical Attitudes" American Sociological Review, 72: 812-830.

Devine, Dennis, Laura Clayton, Benjamin Dunford, Rasmy Seying, and Jennifer Pryce (2000). "Jury Decision Making: 45 Years of Empirical Research on Deliberating Groups". Psychology, Public Policy, and Law, 7:3, 622-727.

Eisenberg, Theodore, Stephen Garvey, and Martin Wells (2001). "Forecasting Life and Death: Juror Race, Religion, and Attitude Toward the Death Penalty". Journal of Legal Studies, 30, 277-311.

Entzel, Pamela, Burton Dunlop and Max Rothman (2000) "Elders and Jury Service: A Case of Age Discrimination" In Rothman, Max, Burton Dunlop and Pamela Entzel (Eds), Elders, Crime, and the Criminal Justice System: Myth, Perceptions, and Reality in the $21^{\text {st }}$ Century, New York, Springer.

Fahey, William (1997) “Peremptory Challenges: A Crucial Tool for Trial Lawyers,” 12 
Glenn, Norval (1974) "Aging and Conservatism" Annals of the American Academy of Political and Social Science Vol 415: 176-186.

Hannaford-Agor, Paula, Valerie Hans, Nicole Mott, G. Thomas Munsterman (2002) “Are Hung Juries a Problem", National Institute of Justice, The National Center for State Courts.

Hoffman, Morris (1997) "Peremptory Challenges Should Be Abolished: A Trial Judge's Perspective," 64 University of Chicago Law Review 809.

Garvey, Stephen, Paula Hannaford-Agor, Valerie Hans, Nicole Mott, G. Thomas Munsterman, and Martin Wells (2004). "Juror First Votes in Criminal Trials". Journal of Empirical Legal Studies, 1:2, 371-398.

J.E.B. v Alabama (1994), ex rel. T.B., 511 U.S. 127

Johnson, Richard and David Neumark (1997) Age Discrimination, Job Separation, and the Employment Status of Older Workers: Evidence from Self-Reports," Journal of Human Resources, 32(4).

Kling, Jeffrey, "Incarceration Length, Employment, and Earnings," American Economic Review, 96 (2006), 863-876.

Kressel, Neil and Dorit Kressel (2004) "Stack and Sway: The New Science of Jury Consulting" Westview Press, Boulder, Colorado, pages 302.

Lisneck, Paul (2003) “the Hidden Jury”Sourcebooks, Inc. Naperville, Illinois. 313.

Macinol, John, (2005) Age Discrimination: An Historical and Contemporary Analysis, Cambridge University Press: Cambridge, UK

Marder, Nancy (1995) "Beyond Gender: Peremptory Challenges and the Roles of the Jury" Texas Law Review, 73, 1041-1138.

Mills, Carol and Wayne Bohannon (1980). "Jury Characteristics: To What Extent Are They Related to Jury Verdicts?" Judicature, 64, 22.

Montz, Vivien and Craig Lee Montz (2000), "The Peremptory Challenge: Should It Still Exist? An Examination of Federal and Florida Law," 54 University of Miami Law Review 451 (2000).

Montoya, Jean (1996) "The Future of Post-Batson Peremptory Challenges: Voir Dire By Questionnaire and the 'Blind Peremptory'”, 29 University of Michigan Journal of Legal Reform 981 (1996).

Moran, Gary and John Craig Comfort (1982). "Scientific Jury Selection: Sex as a Moderator of Demographic and Personality Predictors of Impaneled Felony Juror Behavior". Journal of Personality and Social Psychology, 1052-1054.

Neumark, David and Wendy Stock, (1999), “Age Discrimination Laws and Labor Market Efficiency," The Journal of Political Economy, 107(5).

Overland, Sean G. (2009). The Juror Factor: Race and Gender in America's Civil Courts, LFB Scholarly Publishing 
Page, Anthony (2005), "Batson's Blind-Spot: Unconscious Stereotyping and the Peremptory Challenges," 85 Boston University Law Review 155.

Reid, Glen (2004), "Limitations on Peremptory Challenges: How Far Will They Extend?" 51 Fed. Law 18.

Ruggiero, Josephine and Louise Weston (1977) "Comparative Analysis of Male and Female Attitudes toward Tolerance of Nonconformists." International Journal of Sociology of the Family 7:77-85.

Sengstock, Mary and Jersey Liang (1979) "Attitudes of the Elderly toward the American Legal System." Paper presented at the 1979 Gerontological Society of America, Philadelphia.

State v. Hodge (1999), 248 Conn. 207, 726 A. 2d 531

Thomas, Charles and Robert Howard (1978) "Public Attitudes toward Capital Punishment" In Justice and Corrections, ed. Norman Johnston and Leonard Savitz, 407-17. New York: Wiley.

Vidmar, Neil and Åhoebe Ellsworth (1976) "Public Opinion on the Death Penalty." In Capital Punishment in the United States, ed. Hugo Adam Bedau and Chester Pierce, 125-51. New York: AMS Press.

Weber v. Strippit, Inc. (1999), 186 F.3d 907, 911 (8th Cir.)

Williams, Sherwood, Charles Thomas and B.K. Singh (1983) "Situational Use of Police Force: Public Reactions." American Journal of Police 3:37-50. 
Figure 1: The Relationship Between Average Pool Age (Empaneled Jury Age) and Conviction Rates

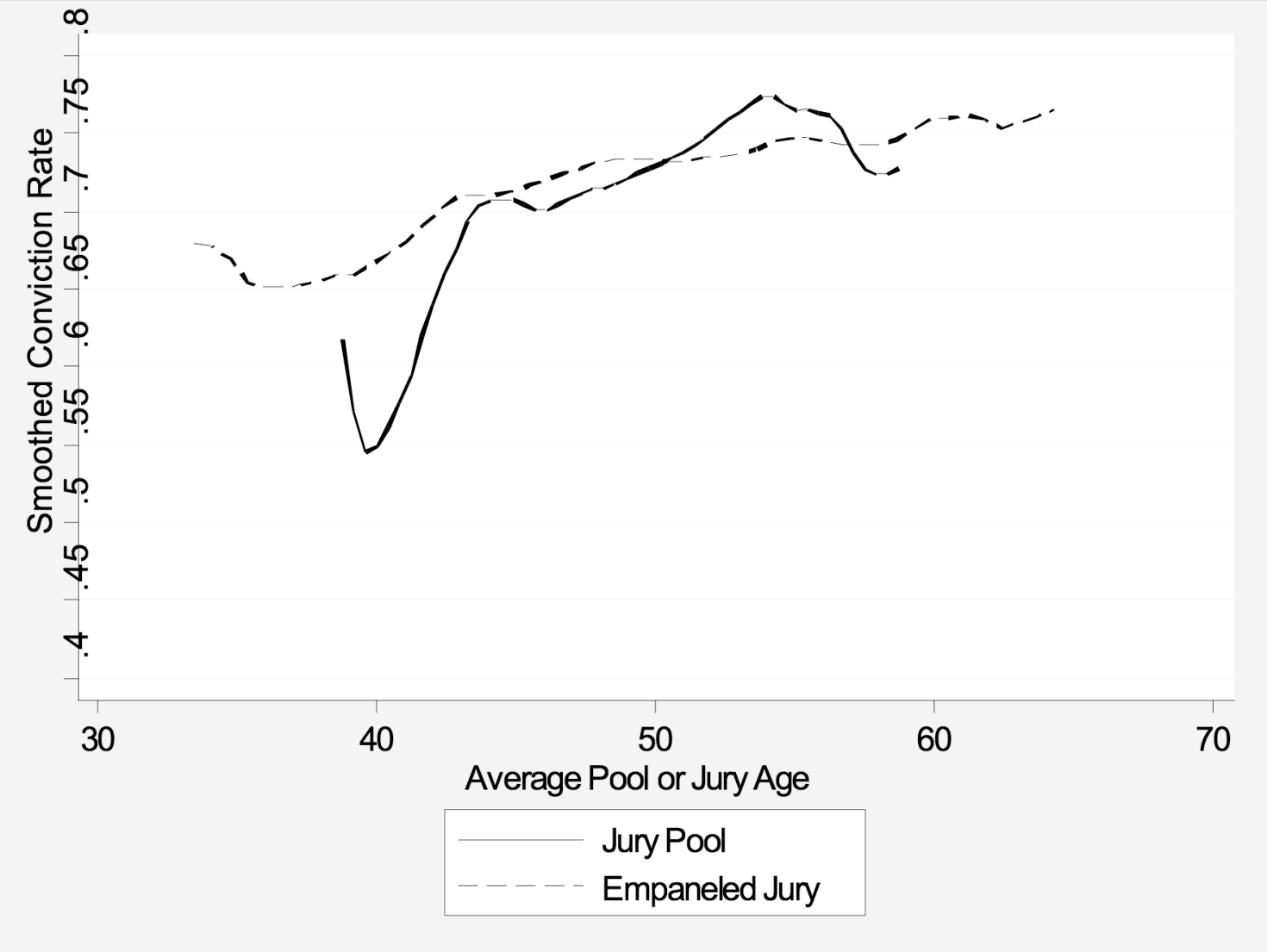

Note: The above graph presents a kernel based smoothed local average estimate of at least one conviction versus the average age of the jury pool and the average age of the empaneled jury. It is estimated using a Rule of Thumb Bandwidth, which is .835 for average pool age and 1.455 for average empaneled jury age. 
Figure 2: The Relationship Between the Average Age of the Jury Pool and Empaneled Jury

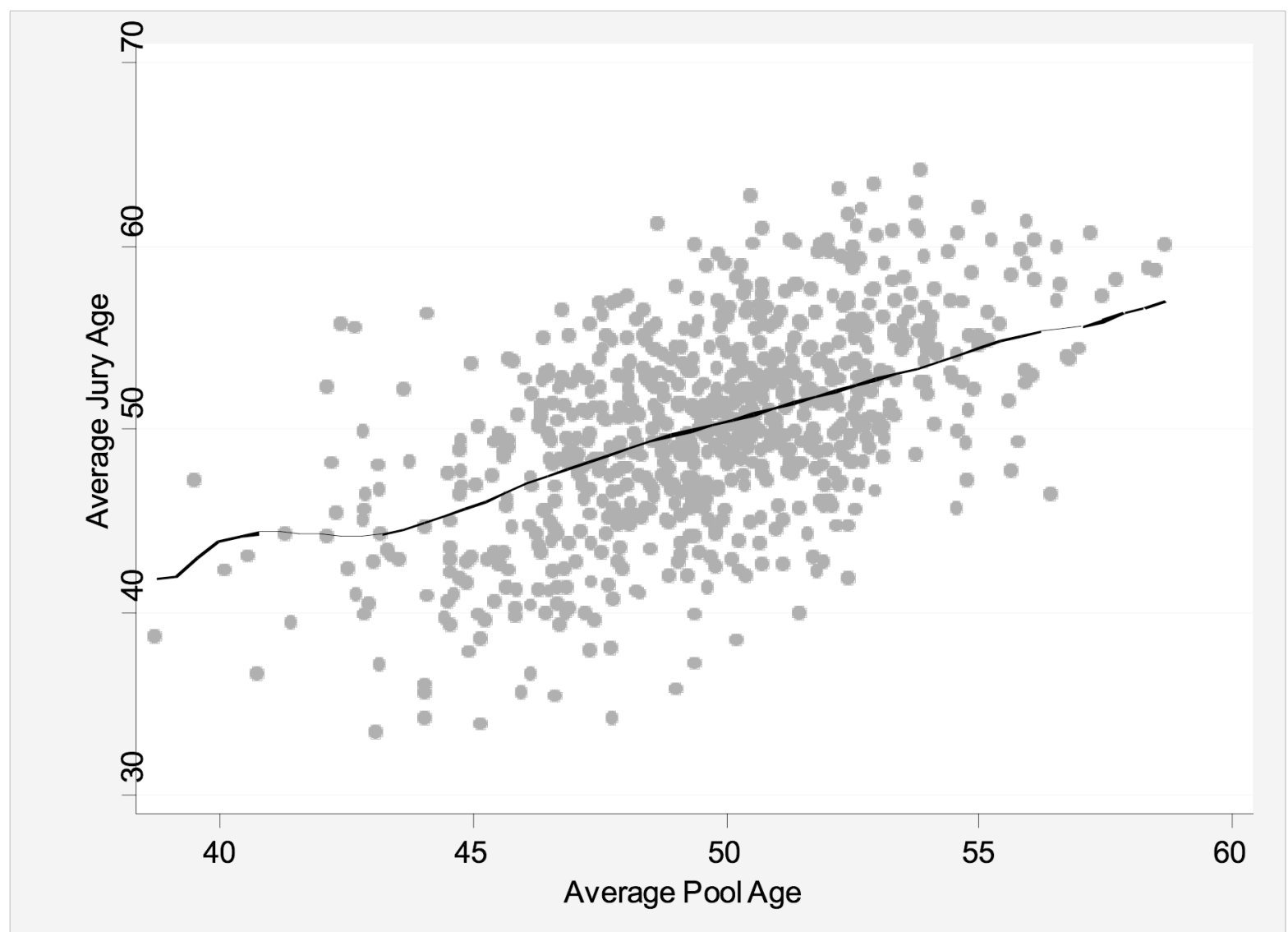

Note: The above graph presents a scatterplot of the average jury age versus the average pool age as well as a kernel based smoothed local average estimate of the average jury age - pool age relationship. The latter is estimated using a Rule of Thumb Bandwidth, which is .835 for average pool age. 
Figure 3: Evidence of the Age-Conservatism Relationship From the 1972-2010 General Social Surveys

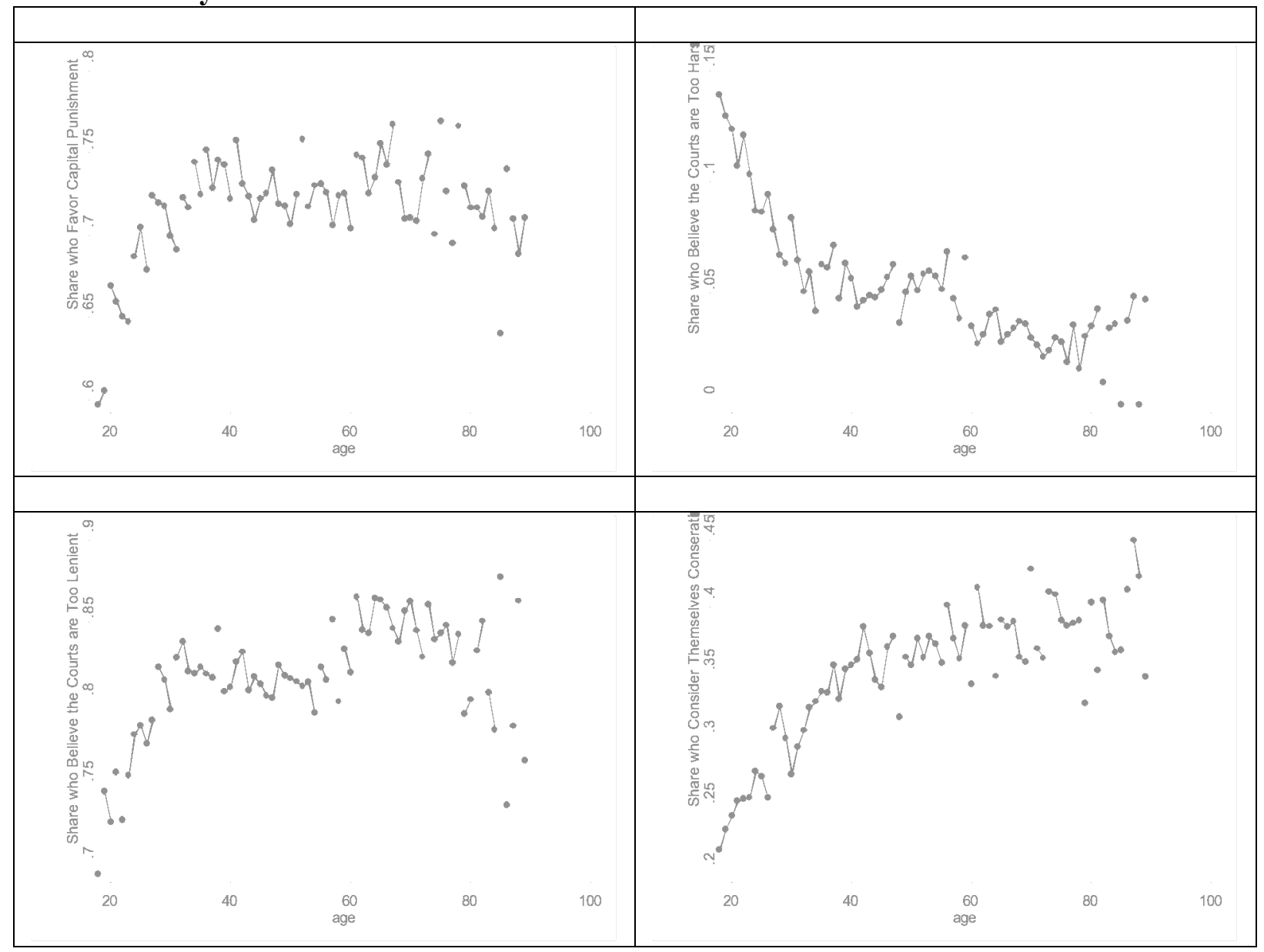




\begin{tabular}{|c|c|c|c|c|c|c|}
\hline & \multicolumn{2}{|c|}{$\begin{array}{l}\text { All Lake and } \\
\text { Sarasota Cases }\end{array}$} & \multicolumn{2}{|c|}{ All Lake Cases } & \multicolumn{2}{|c|}{ All Sarasota Cases } \\
\hline & Mean & $\mathrm{Sd}$ & Mean & $\mathrm{Sd}$ & Mean & $\mathrm{Sd}$ \\
\hline \multicolumn{7}{|l|}{ Defendant Characteristics } \\
\hline Black Defendant & 0.439 & 0.497 & 0.501 & 0.501 & 0.382 & 0.486 \\
\hline Hispanic Defendant & 0.043 & 0.202 & 0.024 & 0.154 & 0.06 & 0.238 \\
\hline White Defendant & 0.513 & 0.500 & 0.472 & 0.500 & 0.551 & 0.498 \\
\hline Male Defendant & 0.919 & 0.273 & 0.931 & 0.254 & 0.908 & 0.29 \\
\hline \multicolumn{7}{|l|}{ Case Characteristics } \\
\hline Total Charges & 2.994 & 3.567 & 3.465 & 4.565 & 2.551 & 2.18 \\
\hline Any Drug Charge & 0.253 & 0.435 & 0.219 & 0.414 & 0.284 & 0.452 \\
\hline Any Murder Charge & 0.053 & 0.224 & 0.080 & 0.272 & 0.027 & 0.164 \\
\hline Any Robbery Charge & 0.090 & 0.287 & 0.099 & 0.299 & 0.082 & 0.275 \\
\hline Any Other Violent Charge & 0.307 & 0.461 & 0.349 & 0.477 & 0.267 & 0.443 \\
\hline Any Property Charge & 0.233 & 0.423 & 0.259 & 0.438 & 0.209 & 0.407 \\
\hline Any Sex Charge & 0.131 & 0.338 & 0.128 & 0.335 & 0.135 & 0.342 \\
\hline Any Weapons Charge & 0.120 & 0.325 & 0.160 & 0.367 & 0.082 & 0.275 \\
\hline Any Other Charge & 0.327 & 0.470 & 0.320 & 0.467 & 0.334 & 0.472 \\
\hline \multicolumn{7}{|l|}{ Dependant Variables } \\
\hline Proportion Guilty Convictions & 0.670 & 0.439 & 0.584 & 0.458 & 0.756 & 0.401 \\
\hline Any Guilty Convictions & 0.728 & 0.445 & 0.653 & 0.477 & 0.803 & 0.399 \\
\hline \multicolumn{7}{|l|}{ Pool and Seated Jury Characteristics } \\
\hline Number in Jury Pool & 27.292 & 7.294 & 26.956 & 7.410 & 27.613 & 7.175 \\
\hline Number of Seated Jurors & 7.113 & 0.483 & 7.307 & 0.500 & 6.928 & 0.384 \\
\hline Number of Jurors Struck for Cause & & & 2.229 & 2.357 & & \\
\hline $\begin{array}{l}\text { Number of Jurors Struck by Defense } \\
\text { Number of Jurors Struck by }\end{array}$ & & & 4.469 & 2.177 & & \\
\hline Prosecution & & & 3.383 & 1.874 & & \\
\hline average age of seated jury & 50.102 & 5.468 & 49.380 & 5.280 & 50.794 & 5.561 \\
\hline average age of pool & 49.623 & 3.137 & 49.361 & 3.164 & 49.873 & 3.094 \\
\hline average age of seated jury $>=50$ & 0.526 & 0.500 & 0.477 & 0.500 & 0.574 & 0.495 \\
\hline average age of pool $>=50$ & 0.461 & 0.499 & 0.424 & 0.495 & 0.496 & 0.501 \\
\hline Observations & 785 & & 384 & & 401 & \\
\hline
\end{tabular}

Note: The columns report summary statistics for the sample of cases for which a jury was selected and the variable under consideration is defined. In the first column, defendant race is defined for 774 cases, defendant gender for 776 cases, specific crime categories for 776 cases, total charges for 773 cases, the dependant variables for 750 cases, and the pool and seated jury variables for the full sample of 785 cases. Summary statistics for the proportion and average variables (i.e., proportion guilty convictions, average age of seated jury, and average age of pool) were formed by measuring the relevant proportion or average for each jury/jury pool and then averaging across cases. 


\begin{tabular}{|c|c|c|c|c|}
\hline & (1) & $\begin{array}{c}\text { (2) } \\
\text { indicator for } \\
\text { whether juror } \\
\text { is }>=50\end{array}$ & $\begin{array}{c}\text { (3) } \\
\text { indicator for } \\
\text { whether juror is } \\
\text { male }\end{array}$ & $\begin{array}{c}\text { (4) } \\
\text { indicator for } \\
\text { whether juror is } \\
\text { black }\end{array}$ \\
\hline struck for cause & $\begin{array}{c}0.683 \\
(0.534)\end{array}$ & $\begin{array}{c}0.0245 \\
(0.0195)\end{array}$ & $\begin{array}{c}-0.0394 * * \\
(0.0195)\end{array}$ & $\begin{array}{c}0.0119 \\
(0.0103)\end{array}$ \\
\hline struck by defense & $\begin{array}{c}2.186^{* * * *} \\
(0.417)\end{array}$ & $\begin{array}{c}0.0622 * * * \\
(0.0152)\end{array}$ & $\begin{array}{l}-0.0160 \\
(0.0153)\end{array}$ & $\begin{array}{c}-0.0362 * * * \\
(0.00614)\end{array}$ \\
\hline struck by prosecution & $\begin{array}{c}-2.321 * * * \\
(0.488)\end{array}$ & $\begin{array}{c}-0.0465 * * * \\
(0.0168)\end{array}$ & $\begin{array}{r}-0.00513 \\
(0.0168)\end{array}$ & $\begin{array}{c}-0.0160 * * \\
(0.00762)\end{array}$ \\
\hline remained in pool & $\begin{array}{c}-0.340 \\
(0.350)\end{array}$ & $\begin{array}{l}-0.0189 \\
(0.0127)\end{array}$ & $\begin{array}{l}-0.0163 \\
(0.0127)\end{array}$ & $\begin{array}{l}-0.00757 \\
(0.00612)\end{array}$ \\
\hline constant & $\begin{array}{c}49.38 * * * \\
(0.259)\end{array}$ & $\begin{array}{c}0.5246 * * * \\
(0.0094)\end{array}$ & $\begin{array}{l}0.503 * * * \\
(0.00944)\end{array}$ & $\begin{array}{c}0.0630 * * * \\
(0.00468)\end{array}$ \\
\hline Observations & 10185 & 10185 & 10185 & 9753 \\
\hline R-squared & 0.008 & 0.004 & 0.000 & 0.004 \\
\hline
\end{tabular}


Table 3: The Relationship Between Juror Age Group and Reason for Dismissal in Lake County

(1)

indicator for whether juror is struck for cause
(2)

indicator for whether juror is struck by defense
(3)

indicator for whether juror is struck by prosecution
Age Between 30-40
$-0.0101$
$0.0247 *$
$-0.0561 * * *$
(0.0103)
(0.0131)
(0.0141)
Age Between 40-50

$$
0.00509
$$
$0.0332 * * *$
$-0.0587 * * *$
(0.00995)
(0.0123)
(0.0133)
Age Between 50-60

$$
\begin{gathered}
0.00174 \\
(0.00980)
\end{gathered}
$$
$0.0530 * * *$
$-0.0622 * * *$
(0.0124)
(0.0132)
Age $>60$
0.0108
$0.0699 * * *$
$-0.0790 * * *$
(0.00978)
(0.0124)
(0.0129)
Constant

$$
(0.0162)
$$$$
0.0976^{* * *}
$$
$0.133 * * *$
$0.195 * * *$
(0.0198)
(0.0197)

\begin{tabular}{llll}
\hline Observations & 10185 & 10185 & 10185 \\
R-squared & 0.002 & 0.006 & 0.005 \\
\hline
\end{tabular}

Note: The omitted category is an indicator for whether the juror is age 30 or younger. All regressions use OLS and report heteroskedasticity-robust standard errors in parentheses. ${ }^{*}, * *$, and $* * *$ indicate statistical significance at the 10 percent, 5 percent, and 1 percent levels, respectively. All specifications include all jurors in the pool for the 384 Lake County Trials and include controls for juror gender and race. 
Table 4: The Relationship between the Demographic Composition of the Jury Pool and Defendant/Case Characteristics

(1)

\begin{tabular}{|c|c|c|c|c|}
\hline & $\begin{array}{c}\text { Average Age } \\
\text { of Pool }\end{array}$ & $\begin{array}{c}\text { Indicator for } \\
\text { whether Average } \\
\text { Age of Pool }>=50\end{array}$ & $\begin{array}{c}\text { Proportion of the } \\
\text { Pool that is } \\
\text { Female }\end{array}$ & $\begin{array}{c}\text { Proportion of the } \\
\text { Pool that is } \\
\text { Black }\end{array}$ \\
\hline \multicolumn{5}{|c|}{ Defendant Characteristics } \\
\hline \multirow[t]{2}{*}{ Black Defendant } & -0.295 & -0.0320 & 0.00110 & 0.00309 \\
\hline & $(0.260)$ & $(0.0405)$ & $(0.00787)$ & $(0.00344)$ \\
\hline \multirow[t]{2}{*}{ Hispanic Defendant } & 0.227 & -0.0474 & 0.0254 & 0.00401 \\
\hline & $(0.679)$ & $(0.0910)$ & $(0.0157)$ & $(0.00821)$ \\
\hline \multirow[t]{2}{*}{ Male Defendant } & $-0.796^{*}$ & $-0.122 *$ & -0.00199 & 0.00579 \\
\hline & $(0.450)$ & $(0.0676)$ & $(0.0119)$ & $(0.00481)$ \\
\hline \multicolumn{5}{|l|}{ Case Characteristics } \\
\hline \multirow[t]{2}{*}{ Any Drug Charge } & 0.222 & 0.0198 & 0.0139 & -0.000316 \\
\hline & $(0.328)$ & $(0.0534)$ & $(0.00995)$ & $(0.00414)$ \\
\hline \multirow[t]{2}{*}{ Any Murder Charge } & 0.159 & -0.0333 & 0.0134 & -0.00224 \\
\hline & $(0.414)$ & $(0.0834)$ & $(0.0137)$ & $(0.00591)$ \\
\hline \multirow[t]{2}{*}{ Any Other Charge } & 0.0812 & -0.0179 & 0.00151 & 0.00229 \\
\hline & $(0.261)$ & $(0.0425)$ & $(0.00811)$ & $(0.00354)$ \\
\hline \multirow{2}{*}{$\begin{array}{c}\text { Any Other Violent } \\
\text { Charge }\end{array}$} & 0.216 & 0.00881 & 0.0121 & 0.00364 \\
\hline & $(0.267)$ & $(0.0440)$ & $(0.00867)$ & $(0.00368)$ \\
\hline \multirow[t]{2}{*}{ Any Property Charge } & 0.0827 & -0.00943 & 0.00693 & $0.0133 * * *$ \\
\hline & $(0.301)$ & $(0.0500)$ & $(0.00958)$ & $(0.00455)$ \\
\hline \multirow[t]{2}{*}{ Any Robbery Charge } & 0.343 & 0.0874 & -0.00171 & -0.00495 \\
\hline & $(0.411)$ & $(0.0662)$ & $(0.0136)$ & $(0.00503)$ \\
\hline \multirow[t]{2}{*}{ Any Sex Charge } & 0.572 & 0.0751 & 0.0200 & 0.00189 \\
\hline & $(0.402)$ & $(0.0639)$ & $(0.0122)$ & $(0.00465)$ \\
\hline \multirow[t]{2}{*}{ Any Weapons Charge } & 0.157 & -0.0470 & 0.00499 & -0.00139 \\
\hline & $(0.332)$ & $(0.0572)$ & $(0.0112)$ & $(0.00397)$ \\
\hline \multirow[t]{2}{*}{ Total Charges } & -0.0422 & -0.00464 & -0.000299 & 0.0000555 \\
\hline & $(0.0388)$ & $(0.00622)$ & $(0.00128)$ & $(0.000253)$ \\
\hline \multirow[t]{2}{*}{ Constant } & $50.30 * * *$ & $0.593 * * *$ & $0.496 * * *$ & $0.0276^{* * *}$ \\
\hline & $(0.473)$ & $(0.0744)$ & $(0.0132)$ & $(0.00566)$ \\
\hline Observations & 771 & 771 & 771 & 771 \\
\hline F-Statistic & 0.67 & 0.84 & 0.78 & 1.13 \\
\hline R-squared & 0.01 & 0.01 & 0.009 & 0.023 \\
\hline
\end{tabular}

Note: All regressions use OLS and report heteroskedasticity-robust standard errors in parentheses. *, **, and *** indicate statistical significance at the 10 percent, 5 percent, and 1 percent levels, respectively. The crime categories are not mutually exclusive, so there is no omitted crime category. F-statistics jointly testing whether all coefficients equal zero are reported in the second to last row of the table. Fourteen observations from the full sample shown in Table 1 were dropped due to one or more missing values for the various defendant and case characteristics. 
Table 5: Cross Tabulations of Conviction Rates and Age Composition of Jury Pool

\begin{tabular}{|c|c|c|c|c|}
\hline & & $\begin{array}{c}\text { No Guilty } \\
\text { Verdicts }\end{array}$ & $\begin{array}{l}\text { At Least One } \\
\text { Guilty Verdict }\end{array}$ & $\begin{array}{c}\text { Conviction } \\
\text { Rate }\end{array}$ \\
\hline \multirow{4}{*}{ 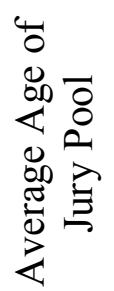 } & $<45$ & 19 & 31 & $62 \%$ \\
\hline & $45-50$ & 112 & 243 & $68 \%$ \\
\hline & $50-55$ & 64 & 252 & $80 \%$ \\
\hline & $55-60$ & 9 & 20 & $69 \%$ \\
\hline
\end{tabular}

Note: 35 observations from the full sample used in Table 1 were dropped because none of the charged offenses for those trials resulted in a verdict of guilty or not guilty by the jury. All but two observations in the less than 45 age group have an average age between $40-45$. 
Table 6: Reduced Form Regressions of Relationship Between Conviction Rates and Age of Jury Pool

(1)

(4)

(5)

(6)

(7)

(8)

Any Guilty Conviction

Proportion Guilty Convictions

$\begin{array}{ccccc}\begin{array}{c}\text { Average Age } \\ \text { of Pool }\end{array} & 0.0104^{*} & 0.00891^{*} & 0.00761 & 0.00525 \\ & (0.00534) & (0.00538) & (0.00527) & (0.00537)\end{array}$

Average Age

of Pool $>=50$

$\begin{array}{rr}0.112 * * * & 0.116 * * * \\ (0.0320) & (0.0333)\end{array}$

$0.0914 * * * \quad 0.0899 * * *$

$(0.0318) \quad(0.0331)$

Constant

$\begin{array}{cccc}0.210 & 1.231 * * & 0.677 * * * & 1.673 * * * \\ (0.267) & (0.602) & (0.0233) & (0.540)\end{array}$

0.292

$1.301 * * \quad 0.628 * * * \quad 1.577 * * *$

$(0.267)$

$(0.602) \quad(0.0233) \quad(0.540)$

(0.263)

(0.596)

$(0.0227) \quad(0.536)$

\begin{tabular}{ccccccccc}
\hline Controls & none & full & none & full & none & full & none & full \\
Observations & 750 & 743 & 750 & 743 & 750 & 743 & 750 & 743 \\
R-Squared & 0.005 & 0.119 & 0.016 & 0.131 & 0.003 & 0.117 & 0.011 & 0.125 \\
\hline
\end{tabular}

Note: The dependant variable for each regression is shown in the row heading. All regressions are estimated on the main analysis sample using OLS and heteroskedasticity-robust standard errors are reported in brackets. *,**, and *** indicate statistical significance at the 10 percent, 5 percent, and 1 percent levels, respectively. The full set of controls (used in the even-numbered columns) include controls for the racial and gender composition of the jury pool, defendant and case characteristics (race, gender, offense category and number of offenses), as well as county, year and judge controls. 
Table 7: Robustness of Main Result to Defendant Gender and Race

Dependent Variable = Any Guilty Conviction

(1)

(2)

\begin{tabular}{|c|c|c|c|c|}
\hline Average Age of Pool & $\begin{array}{c}0.0109^{*} \\
(0.00583)\end{array}$ & & $\begin{array}{c}0.0109 \\
(0.00819)\end{array}$ & \\
\hline Female Defendant & $\begin{array}{c}2.529 * * * \\
(0.928)\end{array}$ & $\begin{array}{c}0.282 * * * \\
(0.0755)\end{array}$ & & \\
\hline Average Age of Pool* Female Defendant & $\begin{array}{c}-0.0488 * * * \\
(0.0185)\end{array}$ & & & \\
\hline Average Age of Pool $>=50$ & & $\begin{array}{c}0.131 * * * \\
(0.0343)\end{array}$ & & $\begin{array}{c}0.145 * * * \\
(0.0481)\end{array}$ \\
\hline Average Age of Pool $>=50 *$ Female Defendant & & $\begin{array}{c}-0.365 * * * \\
(0.126)\end{array}$ & & \\
\hline Black Defendant & & & $\begin{array}{l}0.0530 \\
(0.624)\end{array}$ & $\begin{array}{c}0.0825 \\
(0.0504)\end{array}$ \\
\hline Average Age of Pool * Black Defendant & & & $\begin{array}{c}0.000303 \\
(0.0126)\end{array}$ & \\
\hline Average Age of Pool $>=50 *$ Black Defendant & & & & $\begin{array}{l}-0.0287 \\
(0.0741)\end{array}$ \\
\hline Constant & $\begin{array}{c}0.187 \\
(0.290)\end{array}$ & $\begin{array}{c}0.664 * * * \\
(0.0240)\end{array}$ & $\begin{array}{c}0.156 \\
(0.406)\end{array}$ & $\begin{array}{c}0.626 * * * \\
(0.0336)\end{array}$ \\
\hline Observations & 746 & 746 & 710 & 710 \\
\hline R-squared & 0.135 & 0.154 & 0.130 & 0.152 \\
\hline
\end{tabular}

Note: All regressions use OLS and report heteroskedasticity-robust standard errors in parentheses. *, **, and *** indicate statistical significance at the 10 percent, 5 percent, and 1 percent levels, respectively. Columns 1 and 2 include demeaned controls for jury gender, race, and county, which are fully interacted with defendant gender, as well as demeaned controls for defendant race, crime type and total charges which are fully interacted with the age measure of the jury pool. Columns 3 and 4 include demeaned controls for jury gender, race and county which are fully interacted with defendant race, as well as demeaned controls for defendant gender, crime type, and total charges which are fully interacted with the age measure of the jury pool. Columns 3 and 4 restrict the sample to cases with black and white defendants only. 
Table 8: Robustness/Sensitivity Checks

Dependent Variable $=$ Any Guilty Conviction

(1)

(2)

(3)

(4)

(5)

(6)

\begin{tabular}{|c|c|c|c|c|c|c|}
\hline Average Age of Pool $>=50$ & $\begin{array}{l}0.0858 * \\
(0.0519)\end{array}$ & $\begin{array}{c}0.123 * * * \\
(0.0449)\end{array}$ & $\begin{array}{c}0.084 * * * \\
(0.0289)\end{array}$ & $\begin{array}{c}0.092 * * * \\
(0.0301)\end{array}$ & $\begin{array}{c}0.116^{* * *} \\
(0.0339)\end{array}$ & $\begin{array}{c}0.112 * * * \\
(0.0323)\end{array}$ \\
\hline Constant & $\begin{array}{l}1.135 * \\
(0.656)\end{array}$ & $\begin{array}{l}1.703 * * \\
(0.753)\end{array}$ & $\begin{array}{c}1.697 * * * \\
(0.4386)\end{array}$ & $\begin{array}{l}1.413 * * * \\
(0.4767)\end{array}$ & $\begin{array}{l}1.920 * * * \\
(0.5440)\end{array}$ & $\begin{array}{c}1.590 * * * \\
(0.530)\end{array}$ \\
\hline Sample Notes & $\begin{array}{l}\text { Lake } \\
\text { County }\end{array}$ & Sarasota County & $\begin{array}{l}\text { Includes all } \\
\text { Lake cases } \\
\text { that are pled } \\
\text { as guilty jury } \\
\text { verdict }\end{array}$ & $\begin{array}{c}\text { Includes } \\
\text { only Lake } \\
\text { cases that are } \\
\text { pled after the } \\
\text { jury is seated } \\
\text { as guilty jury } \\
\text { verdict }\end{array}$ & $\begin{array}{c}\text { Includes } \\
\text { Sarasota } \\
\text { non-verdict } \\
\text { cases as not } \\
\text { guilty jury } \\
\text { verdict }\end{array}$ & $\begin{array}{l}\text { Includes } \\
\text { Sarasota } \\
\text { non-verdict } \\
\text { cases as } \\
\text { guilty jury } \\
\text { verdict }\end{array}$ \\
\hline Observations & 372 & 371 & 883 & 838 & 768 & 768 \\
\hline R-squared & 0.101 & 0.158 & 0.0932 & 0.1008 & 0.1147 & 0.1313 \\
\hline
\end{tabular}

Note: All regressions use OLS and report heteroskedasticity-robust standard errors in parentheses. *,**, and *** indicate statistical significance at the 10 percent,

5 percent; and 1 percent levels, respectively. All regressions include the full set of controls described in Table 6 . 
Table 9: The First Stage Relationship Between Age of the Seated Jury and Age of the Jury Pool

Average Age of Seated Jury

(1)

(2)

(3)

Average Age of Seated Jury $>=50$

\begin{tabular}{|c|c|c|c|c|c|c|}
\hline & (1) & (2) & (3) & (4) & (5) & (6) \\
\hline Average Age of Pool & $\begin{array}{l}0.943 * * * \\
(0.0568)\end{array}$ & & $\begin{array}{l}0.906 * * * \\
(0.0873)\end{array}$ & $\begin{array}{l}0.0677 * * * \\
(0.00491)\end{array}$ & & $\begin{array}{c}0.0613 * * * \\
(0.00793)\end{array}$ \\
\hline $\begin{array}{l}\text { Average Age of } \\
\text { Pool }>=50\end{array}$ & & $\begin{array}{c}4.605 * * * \\
(0.372)\end{array}$ & $\begin{array}{c}0.291 \\
(0.535)\end{array}$ & & $\begin{array}{c}0.343 * * * \\
(0.0366)\end{array}$ & $\begin{array}{c}0.0514 \\
(0.0575)\end{array}$ \\
\hline Constant & $\begin{array}{l}-2.911 \\
(6.128)\end{array}$ & $\begin{array}{c}38.39 * * * \\
(5.777)\end{array}$ & $\begin{array}{l}-1.219 \\
(7.061)\end{array}$ & $\begin{array}{c}-3.116^{* * *} \\
(0.569)\end{array}$ & $\begin{array}{l}-0.140 \\
(0.568)\end{array}$ & $\begin{array}{c}-2.817 * * * \\
(0.643)\end{array}$ \\
\hline $\begin{array}{l}\text { Observations } \\
\text { R-squared }\end{array}$ & $\begin{array}{c}743 \\
0.367\end{array}$ & $\begin{array}{c}743 \\
0.275\end{array}$ & $\begin{array}{c}743 \\
0.368\end{array}$ & $\begin{array}{c}743 \\
0.227\end{array}$ & $\begin{array}{c}743 \\
0.177\end{array}$ & $\begin{array}{c}743 \\
0.228\end{array}$ \\
\hline
\end{tabular}

5 percent; and 1 percent levels, respectively. All regressions include the full set of controls described in Table 6. 
Table 10: OLS and IV Regressions of the Relationship Between Conviction Rates and Age of Seated Jury

Dependent Variable $=$ Any Guilty Conviction

$\begin{array}{lllll}(1) & (2) & (3) & (4) & (5)\end{array}$

(6) (7)

\begin{tabular}{|c|c|c|c|c|c|c|c|c|}
\hline Avg. Age of Seated Jury & $\begin{array}{c}0.00258 \\
(0.00305)\end{array}$ & $\begin{array}{l}0.00945 * \\
(0.00553)\end{array}$ & $\begin{array}{l}0.0252 * * * \\
(0.00730)\end{array}$ & $\begin{array}{c}0.0101 * \\
(0.00553)\end{array}$ & & & & \\
\hline $\begin{array}{l}\text { Avg. Age of Seated Jury } \\
>=50\end{array}$ & & & & & $\begin{array}{c}0.0378 \\
(0.0329)\end{array}$ & $\begin{array}{c}0.132 * \\
(0.0778)\end{array}$ & $\begin{array}{c}0.338 * * * \\
(0.100)\end{array}$ & $\begin{array}{c}0.152 * \\
(0.0778)\end{array}$ \\
\hline Constant & $\begin{array}{c}1.499 * * * \\
(0.568)\end{array}$ & $\begin{array}{l}1.258 * * \\
(0.581)\end{array}$ & $\begin{array}{c}0.707 \\
(0.636)\end{array}$ & $\begin{array}{l}1.236 * * \\
(0.582)\end{array}$ & $\begin{array}{l}1.604 * * * \\
(0.559)\end{array}$ & $\begin{array}{l}1.640 * * * \\
(0.543)\end{array}$ & $\begin{array}{c}1.721 * * * \\
(0.566)\end{array}$ & $\begin{array}{l}1.649 * * * \\
(0.544)\end{array}$ \\
\hline Method & OLS & $\begin{array}{c}\text { IV } \\
\text { avg age } \\
\text { of pool }\end{array}$ & $\begin{array}{c}\text { IV } \\
\text { avg age of } \\
\text { pool }>=50\end{array}$ & $\begin{array}{l}\text { IV } \\
\text { both }\end{array}$ & OLS & $\begin{array}{c}\text { IV } \\
\text { avg age } \\
\text { of pool }\end{array}$ & $\begin{array}{c}\text { IV } \\
\text { avg age of } \\
\text { pool }>=50\end{array}$ & $\begin{array}{l}\text { IV } \\
\text { both }\end{array}$ \\
\hline First Stage F-statistic & & 275.51 & 153.58 & 138.07 & & 190.49 & 87.79 & 98.03 \\
\hline
\end{tabular}

Note: All regressions report heteroskedasticity-robust standard errors in parentheses. ${ }^{*}, * *$, and $* * *$ indicate statistical significance at the 10 percent,

5 percent; and 1 percent levels, respectively. All regressions include the full set of controls described in Table 6 . 
Table 11: General Social Survey Regression Results

\begin{tabular}{|c|c|c|c|c|c|c|c|c|c|c|c|c|}
\hline & (1) & (2) & (3) & (4) & (1) & (2) & (3) & (4) & (1) & (2) & (3) & (4) \\
\hline & & Courts are & oo Lenient & & & Courts ar & Too Harsh & & & Politically & onservative & \\
\hline \multirow[t]{2}{*}{ age30_39 } & $0.047 * *$ & $0.049 * *$ & $0.042 * *$ & $0.047 * *$ & $-0.034 * *$ & $-0.034 * *$ & $-0.027 * *$ & $-0.034 * *$ & $0.050 * *$ & $0.047 * *$ & $0.017 *$ & -0.001 \\
\hline & {$[0.005]$} & {$[0.005]$} & {$[0.006]$} & {$[0.014]$} & {$[0.003]$} & {$[0.003]$} & [0.003] & [0.009] & {$[0.007]$} & [0.007] & [0.007] & [0.014] \\
\hline \multirow[t]{2}{*}{ age40_49 } & $0.041 * *$ & $0.054 * *$ & $0.046 * *$ & $0.037 * *$ & $-0.044 * *$ & $-0.049 * *$ & $-0.042 * *$ & $-0.053 * *$ & $0.084 * *$ & $0.081 * *$ & $0.042 * *$ & 0.02 \\
\hline & {$[0.006]$} & {$[0.006]$} & {$[0.006]$} & {$[0.014]$} & {$[0.003]$} & {$[0.003]$} & {$[0.004]$} & [0.009] & {$[0.007]$} & {$[0.007]$} & {$[0.007]$} & {$[0.014]$} \\
\hline \multirow[t]{2}{*}{ age50_59 } & $0.042 * *$ & $0.057 * *$ & $0.044 * *$ & $0.030^{*}$ & $-0.038 * *$ & $-0.045^{* *}$ & $-0.037 * *$ & $-0.034 * *$ & $0.098 * *$ & $0.098 * *$ & $0.058 * *$ & 0.026 \\
\hline & {$[0.006]$} & {$[0.006]$} & {$[0.006]$} & [0.015] & [0.004] & [0.004] & [0.004] & {$[0.010]$} & {$[0.007]$} & [0.008] & [0.008] & [0.014] \\
\hline \multirow[t]{2}{*}{ age60_69 } & $0.075 * *$ & $0.082 * *$ & $0.063 * *$ & $0.057 * *$ & $-0.060 * *$ & $-0.063 * *$ & $-0.056^{* *}$ & $-0.065^{* *}$ & $0.102 * *$ & $0.102 * *$ & $0.067 * *$ & $0.045 * *$ \\
\hline & {$[0.006]$} & {$[0.006]$} & {$[0.007]$} & {$[0.017]$} & [0.004] & [0.004] & [0.004] & {$[0.011]$} & {$[0.008]$} & [0.008] & {$[0.008]$} & [0.016] \\
\hline \multirow[t]{2}{*}{ age70_79 } & $0.067 * *$ & $0.071 * *$ & $0.051 * *$ & 0.029 & $-0.068 * *$ & $-0.070 * *$ & $-0.066^{* *}$ & $-0.080 * *$ & $0.115^{* *}$ & $0.113 * *$ & $0.091 * *$ & $0.053 * *$ \\
\hline & {$[0.007]$} & {$[0.007]$} & [0.008] & [0.019] & [0.004] & [0.004] & {$[0.005]$} & [0.013] & [0.009] & [0.009] & {$[0.010]$} & [0.019] \\
\hline \multirow[t]{2}{*}{ age80plus } & $0.036 * *$ & $0.053 * *$ & $0.033 * *$ & 0.014 & $-0.063 * *$ & $-0.071 * *$ & $-0.069 * *$ & $-0.093 * *$ & $0.109 * *$ & $0.107 * *$ & $0.102 * *$ & $0.055^{*}$ \\
\hline & {$[0.010]$} & {$[0.010]$} & {$[0.011]$} & [0.023] & {$[0.006]$} & {$[0.006]$} & {$[0.006]$} & {$[0.015]$} & {$[0.013]$} & {$[0.013]$} & {$[0.013]$} & {$[0.022]$} \\
\hline \multirow[t]{2}{*}{ Male } & & & $-0.041 * *$ & $-0.063 * *$ & & & $0.020 * *$ & $0.032 * *$ & & & $0.050 * *$ & $0.049 * *$ \\
\hline & & & {$[0.004]$} & [0.009] & & & {$[0.002]$} & {$[0.006]$} & & & {$[0.004]$} & {$[0.008]$} \\
\hline \multirow[t]{2}{*}{ White } & & & $0.075 * *$ & $0.102 * *$ & & & $-0.073 * *$ & $-0.097 * *$ & & & $0.072 * *$ & $0.084 * *$ \\
\hline & & & {$[0.005]$} & {$[0.010]$} & & & {$[0.003]$} & {$[0.007]$} & & & {$[0.006]$} & [0.010] \\
\hline \multirow[t]{2}{*}{ years of schooling } & & & $-0.007 * *$ & $-0.014 * *$ & & & -0.001 & 0 & & & $0.006^{* *}$ & $0.003 *$ \\
\hline & & & {$[0.001]$} & {$[0.001]$} & & & {$[0.000]$} & {$[0.001]$} & & & {$[0.001]$} & {$[0.001]$} \\
\hline \multirow[t]{2}{*}{ number of children } & & & $-0.005 * *$ & -0.001 & & & $0.004 * *$ & $0.005^{*}$ & & & $0.010^{* *}$ & $0.017 * *$ \\
\hline & & & {$[0.001]$} & {$[0.003]$} & & & {$[0.001]$} & {$[0.002]$} & & & {$[0.001]$} & {$[0.003]$} \\
\hline \multirow[t]{2}{*}{ Married } & & & $0.052 * *$ & $0.055^{* *}$ & & & $-0.034 * *$ & $-0.054 * *$ & & & $0.066 * *$ & $0.078 * *$ \\
\hline & & & [0.004] & [0.009] & & & {$[0.002]$} & {$[0.006]$} & & & {$[0.005]$} & {$[0.009]$} \\
\hline \multirow[t]{2}{*}{ Constant } & $0.775 * *$ & $0.697 * *$ & $0.721 * *$ & $0.773 * *$ & $0.094 * *$ & $0.110^{* *}$ & $0.180 * *$ & $0.227 * *$ & $0.275 * *$ & $0.310 * *$ & $0.117 * *$ & $0.125 * *$ \\
\hline & {$[0.004]$} & {$[0.011]$} & {$[0.013]$} & {$[0.023]$} & {$[0.002]$} & {$[0.006]$} & {$[0.008]$} & {$[0.015]$} & {$[0.005]$} & {$[0.014]$} & {$[0.018]$} & {$[0.022]$} \\
\hline Observations & 47018 & 47018 & 46788 & 11568 & 47018 & 47018 & 46788 & 11568 & 45860 & 45860 & 45667 & 13431 \\
\hline R-squared & 0 & 0.04 & 0.06 & 0.03 & 0.01 & 0.03 & 0.05 & 0.04 & 0.01 & 0.01 & 0.02 & 0.03 \\
\hline Survey Year Dummies & No & Yes & Yes & No & No & Yes & Yes & No & No & Yes & Yes & No \\
\hline $2000-2010$ survey rounds only & No & No & No & Yes & No & No & No & Yes & No & No & No & Yes \\
\hline
\end{tabular}

Note: Standard errors in brackets. * significant at 5\%; ** significant at 1\%. Columns 1 uses the full sample that has responded and has no controls. Column 2 adds controls for year of survey -- 1972 to 2010 . Column 3 controls for individual characteristics. Column 4 uses just the 2000 to 2010 survey rounds. Omitted age category in columns $2-5$ is 18 to 29. 